\title{
Problems of improving the management of socio-economic subsystems in smart cities
}

\author{
Vladimir Plotnikov 1,2, *, Yulia Vertakova $^{2}$, Yuri Treshchevsky $^{3}$, and Natalia Firsova ${ }^{4}$ \\ ${ }^{1}$ Saint-Petersburg State University of Economics, 21, Sadovaya str., St. Petersburg, Russia, 191023 \\ ${ }^{2}$ South-West State University, 94, 50 let Oktyabrya str., Kursk, Russia, 305040 \\ ${ }^{3}$ Voronezh State University, 1, Universitetskaya sq., Voronezh, Russia, 394036 \\ ${ }^{4}$ Voronezh State Technical University, 84, 20 let Oktyabrya str., Voronezh, Russia, 394006
}

\begin{abstract}
The development of technologies (especially information and communication technologies) has led to changes in economic processes and social life in general. One of the consequences of the information technology revolution is the emergence of the phenomenon of smart cities. There is a large number of publications on the problems of their formation and development. In practice, projects for their creation are being implemented. However, due to the novelty of the phenomenon being studied, its further scientific analysis is required. The main problem in this area, according to the authors, is the development of an effective management system for smart cities. The purpose of the article is to investigate the problems that are associated with the development of smart city management systems. A three-level model for managing their development is proposed. The first level of the model is the management of the development of the urban historical center. At the second level, the city as a whole is managed. The third level is aimed at the formation of an integrated urban agglomeration management system. The main emphasis was made not on the formation and development of digital services, but on the development of traditional urban systems. The authors propose to make them more intelligent, by introducing new technologies. The main measures to develop smart city management systems are organizational.
\end{abstract}

\section{Introduction}

The modern world is rapidly developing. One of the main vectors of its change is technological transformation $[1,2,3$, 4, etc.]. Technology changes affect not only production, but also social processes in general. New technologies contribute to the formation of a new lifestyle, institutional and social structure, new markets, etc. The most rapid and obvious these changes occur in cities.

Over $50 \%$ of the world's population is concentrated in cities. And there are two obvious dependencies: (1) the higher the standard of living in the country, the stronger the country is urbanized; (2) the percentage of urban population is increasing steadily over time

\footnotetext{
*Corresponding author: plotnikov_2000@mail.ru
} 
(Table 1). Therefore, the development of new technologies affects, above all, the urban population.

Advanced technological development led to the formation of a new phenomenon, which was named "smart city" [5, 6, etc.]. Electricity networks, water supply systems, city transport and other municipal infrastructure of this cities become intellectual. This makes it possible to solve problems of city management more efficiently. Management in smart cities is based on a developed information and communication infrastructure, covering all the basic subsystems of urban economy.

Table 1. Percentage of Population at Mid-Year Residing in Urban Areas.

\begin{tabular}{|l|c|c|c|}
\hline \multicolumn{1}{|c|}{ Regions, countries } & 1950 & 2018 & 2050 \\
\hline World & 29.6 & 55.3 & 68.4 \\
\hline More developed regions & 54.8 & 78.7 & 86.6 \\
\hline Less developed regions & 17.7 & 50.6 & 65.6 \\
\hline Least developed countries & 7.5 & 33.6 & 52.5 \\
\hline $\begin{array}{l}\text { Less developed regions, excluding least developed } \\
\text { countries }\end{array}$ & 19.0 & 53.9 & 69.4 \\
\hline Less developed regions, excluding China & 20.3 & 48.0 & 62.7 \\
\hline High-income countries & 58.5 & 81.5 & 88.4 \\
\hline Middle-income countries & 19.9 & 52.6 & 68.3 \\
\hline Upper-middle-income countries & 22.1 & 66.6 & 82.6 \\
\hline Lower-middle-income countries & 17.2 & 40.6 & 59.0 \\
\hline Low-income countries & 9.3 & 32.2 & 50.2 \\
\hline
\end{tabular}

Source: United Nations, Department of Economic and Social Affairs, Population Division (2018). World Urbanization.

In the new century, the city's efficiency will largely depend on whether we are able to competently manage energy and water resources. Now it is necessary to rebuild the entire industry in such a way as to ensure that available resources meet ever-increasing demand. Together, we will be able to modernize the power grid, build intelligent cities, open up new opportunities for interaction with the population and improve the management of such valuable resources as gas, water and electricity, using innovative technologies. This will allow not only to attract new companies to the city, but also to strengthen its reputation as a center for sustainable and balanced development. Thanks to innovative technologies and joint work, we will be able to create intelligent cities and open new economic opportunities.

\section{Short literature review}

The priority strategic goals of urban development in smart cities are: (1) to achieve the city's leadership positions in the development of human capital / potential; (2) sustainable development of the city's economy based on the innovation sector; (3) effective spatial development. Studying problems of smart cities is the new phenomenon [7, 8]. The key components of the smart city concept are: (1) management and organization, (2) technology, (3) politics, (4) context, (5) people and communities, (6) economics, (7) construction, (8) infrastructure, (9) the natural environment [9].

The results of some studies indicate that local conditions are of great importance for the implementation of the smart city concept [10]. For this reason, the authors of the article believe that the general theoretical positions of the concept of a smart city should be adapted to the country and regional conditions. For example, the specialists of the Indian Ministry of Housing and Urban Affairs have a similar position: "A smart city would have a different connotation in India than, say, Europe. Even in India, there is no one way of 
defining a smart city" [11]. This gives rise to a variety of options for the formation and development of smart cities. Different authors pay attention to the need for the "smart governments" for smart cities [12]. We concluded that the key factor in the successful development of smart cities is effective management.

Smart city is an efficiently managed city [13]. Thus, it is necessary to take into account the different purposes of the functional subsystems of the city. For example:

- Residents need the convenience of obtaining various services and their payment, including housing and communal services, transport, parking, medical and public services, fast Internet and other.

- City authorities need the public safety, effective management of emergency and operational services, management up to and planning of expenses and incomes, environmental monitoring, transparent provision of educational and medical services and other.

Despite the existence of a sufficiently large number of studies on the problem of smart cities, this concept requires further development. This is determined by: first, the specific features of these cities that we have noted, which requires study; secondly, the novelty of this phenomenon, which in science has not yet received a clear understanding. The main problem in this area, in our opinion, is the development of an effective management system for smart cities.

\section{Purpose of the study}

The purpose of the article is to investigate the problems that are associated with the development of smart city management systems. At the same time, the focus is not on information and technology aspects of smart city management, but on organizational and technical aspects. This formulation of the task is due to the fact that the convenience of living and doing business in the city should be determined by transport accessibility, environmental friendliness, the availability of comfortable recreation areas, etc.

The author's position is confirmed by the composition of the indicators that are included in the Smart Cities Index (Table 2), developed by EasyPark Group. This organization explores which cities are the most prepared for the future. In addition to evaluating digital metrics (4G, Wi-Fi hotspots, smartphone usage, etc.), Smart Cities Index takes into account traditional indicators. The rating includes the following indicators: Transport and mobility; Sustainability; Governance; Innovation Economy; Digitalization; Living Standard; Expert Perception.

Table 2. TOP-10 of Smart Cities Index, 2017.

\begin{tabular}{|c|l|l|c|}
\hline Rank & \multicolumn{1}{|c|}{ City } & \multicolumn{1}{|c|}{ Country } & Score \\
\hline 1 & Copenhagen & Denmark & 8.24 \\
\hline 2 & Singapore & Singapore & 7.83 \\
\hline 3 & Stockholm & Sweden & 7.82 \\
\hline 4 & Zurich & Switzerland & 7.75 \\
\hline 5 & Boston & United States & 7.70 \\
\hline 6 & Tokyo & Japan & 7.59 \\
\hline 7 & San Francisco & United States & 7.55 \\
\hline 8 & Amsterdam & Netherlands & 7.54 \\
\hline 9 & Geneva & Switzerland & 7.53 \\
\hline 10 & Melbourne & Australia & 7.51 \\
\hline
\end{tabular}

Source: EasyPark Group (2018); https://easyparkgroup.com/smart-cities-index. 
Smart city must be sustainable, with a focus on clean energy and environmental projection. It must have an excellent online access to governmental services and a high level of citizen participation. These cities should be comfortable for living. This requires upgrading the smart city management system.

\section{Results and its discussion}

Emerging negative effects in many Russian cities require the use of new mechanisms for regulating its spatial and socio-economic development. A similar situation is observed in other countries. Many cities have poor zoning. This is due to historical and institutional reasons. Many Russian cities were initially created as workers' settlements in large industrial enterprises. For example, the development of oil and gas production in Western Siberia in the 1960s-1980s led to the emergence of a number of new cities (Nizhnevartovsk, Surgut, Nefteyugansk, Nyagan, Kogalym, Langepas, Megion, Nadym, Novy Urengoy, Strezhevoy).

A significant impetus to urbanization in Russia was given by the industrialization of the first third of the 20th century. The industrial development projects implemented during the first five-year plans have spawned many new cities, including specialized ones. Investments mainly in industry led to the rapid growth of new cities. This led to a problem. There was a situation when "growth" outstripped "development". The industry sometimes deprived resources of other activities. With the accelerated development of industry, the deterioration of the ecological situation is also often associated.

A typical example is the Russian city of Norilsk. It was built in the 1930s. The economy of the city is based on the mining industry, extraction and primary processing of nonferrous and precious metals. This city is constantly included in top-10 of the most environmentally "dirty" Russian cities (data of Russian state and public organizations). Norilsk is the main polluter of the Arctic. According to Greenpeace, it is included in top-10 of the most environmentally "dirty" cities on the planet. The situation began to change in recent years. This happened after the closure in 2016 of the Nickel Plant. This enterprise was located in the historical center of the city. It annually emitted about 0.4 million tons of sulfur dioxide into the atmosphere.

The development of the city "around" a large enterprise or an industrial group is a typical scenario of the historical evolution of cities in many countries. Such development over time forms an inefficient zoning of the city's territory. In its center, along with the administrative zone, an industrial zone is being created. In the course of time, after changing the priorities of urban development, the reconstruction and the reduction in the production areas in the central zone of the city is required. This territories must acquire a new functional purpose (public and business centers, science parks, technology parks, including IT parks, walking areas, etc.).

It is necessary to carry out dispersed functional division of industrial zones with the introduction into their territory of service elements of the population and the system of gardening as part of the ecological framework of the citywide structure. The change in the production structure requires an increase in the efficiency of resource consumption and environmental management in the territories of development zones that have reserves for spatial development, technological measures to reduce negative loads to the permitted standards.

Spatial isolation of production and residential areas required changes in the system of engineering support for streets and yard territories. In this regard, the first priority was the formation of comfortable and friendly environment, requiring the following actions:

- The introduction of a centralized street lighting control system.

- The introduction of a management system for street lighting networks via the Internet. 
- The creation of a single data center and management of activities in the sphere of housing and communal services of the city, using fiber-optic technologies, GSM and GPRS terminals, wireless modules and other modern equipment.

- Creation of smart quarters - territories, on which the most progressive world technologies in life support sphere (smart infrastructure, house, garbage disposal, improvement, etc.) should be introduced.

An important problem of a modern city, especially of a large city, is the organization of the traffic. The solving of this problem is requiring the introduction of advanced digital technologies and vehicle upgrades. In this area it is possible to propose:

- Introduction of an adaptive traffic management system.

- Creation of a single intellectual system for managing the parking space of the city with the arrangement of paid urban parking facilities on the basis of a concession agreement for the creation and operation of a paid parking management system.

- Purchase of urban passenger road transport of a new generation.

- Modernization of the dispatching system for passenger transport using navigation systems.

- Introduction of an electronic payment system for travel in public transport.

- Creation of a network of smart stops of public transport.

It is generally accepted that the development of smart cities is determined by the introduction of modern technologies. First of all, we are talking about information and communication technologies. We agree with this point of view. At the same time, an important contribution to the formation and development of smart cities is the organizational modernization of the city management system. Bad zoning, suboptimal street network, incoherence of spatial solutions and similar problems can not be solved due to digitalization. To solve them, organizational and technical measures are needed.

Among the organizational and technical measures, a significant effect can be brought: (1) actualization of the Master plan, local standards of city-planning design, land use rules and development of the urban districts; (2) active position of city authorities in the search for and attraction of investors, defending the interests of the city in the implementation of private projects in urban areas; (3) ensuring the flexibility of the management system in order to take into account the rapid changes in the situation, technological structures, the emergence of new industries, etc.; (4) creation and improvement of the complex automated information system in the field of architecture and town planning; (5) ensuring the coherence of city plans and municipalities forming part of the urban agglomeration, implementing investment projects, housing, social, infrastructure construction through the creation of inter-municipal consultative and coordinating forms of management; (6) intellectualization of the economy and spatial development (promotion of smart and environmentally friendly technologies, smart environments, smart systems and smart industries, including transport, houses, neighborhoods, etc.).

We propose the concept of three-level spatial development of the smart city. The implementation of a three-level model requires the use of three basic principles in city management: the principle of integration; the principle of metabolism; the principle of the architectural quality of the urban environment.

At the first level (the historical center), it is necessary to raise the level of architectural solutions and functional saturation of the historic part of the city in combination with preserving historical and cultural monuments, improving the organization of traffic, landscaping, planting a network of pedestrian and bicycle routes. Typical problems of the central part of cities are: the presence of transit traffic of vehicles, the contrast of highdensity and low-density buildings, the limited space of public spaces, the violation of architectural and compositional development, the limited planning relationships of different territories. Spatial-territorial reserves of city centers are usually inhomogeneous. In this 
regard, it is expedient to identify and reconstruct the territories of urban centers that are promising from the point of view of complex development of cities.

The second level (the city as a whole) requires a qualitative organization and a reorganization of the urban environment with priority development of urban municipal services, modernization of the street network, housing stock, improvement of residential and public areas. Practical implementation of the concept provides: elimination of disproportions in providing the city with transport, engineering and social infrastructure; consistent optimization of built-up areas; increase of aesthetic qualities of new architectural complexes and open urban spaces; preservation of territorial reserves for the subsequent transformation of the urban environment in accordance with modern challenges, etc.

The third level (urban agglomeration) is the development of the agglomeration as a zone of interrelated relations, the joint solution of questions of economics, transport, engineering, social well-being, ecology, use of territorial, labor, natural-resource potential. Practical implementation of the concept at the agglomeration level provides: integrated development of transport and logistics infrastructure, including road, rail, air, pedestrian and transport hubs; optimization of transport and pedestrian traffic; decrease in the level of accidents on the roads of the city, etc.

\section{Conclusions}

Smart cities are a new phenomenon. They are actively developing, thanks to the introduction of new technologies in the city economy, first of all - information and communication technologies. As a result of this, the city's management becomes more intelligent. The main goal of creating smart cities is to increase their attractiveness for temporary or permanent residence and business. In this connection, the technical modernization of urban systems should not be limited. It is necessary to take a complex of organizational measures to improve the management of smart cities.

We propose the introduction of a three-level smart city management system. The model of three-level spatial development aimed at achieving the three strategic goals: to achieve the city's leadership positions in terms of the level of human capital / potential development and the quality of life of the population, and the reduction of socio-economic inequality; maintenance of sustainable development of the economy on the basis of the development of the innovation sector and improvement of the business environment; effective spatial development, formation of aesthetically attractive, friendly, comfortable urban environment.

\section{References}

1. K. Schwab. The Fourth Industrial Revolution. World Economic Forum, (Geneva, 2016).

2. M.V. Dubovik, R.V. Gubarev, N.E. Bondarenko, E.I. Dzyuba. Evaluation of innovative development of Russian regions on the basis of neural network simulation. International Journal of Pure and Applied Mathematics, 119, 10, (2018).

3. Y. Vertakova, V. Plotnikov. Problems of sustainable development worldwide and public policies for green economy. Economic Annals-XXI, 166, 7-8, (2017).

4. V.I. Lutin, E.N. Desyatirikova, O.V. Kuripta, N.V. Akamsina, V.E. Mager. The processing of signals from sensors to observe objects in various physical fields. Proc. of the 2018 IEEE Conf. of Russian Young Researchers in Electrical and Electronic Engineering, ElConRus 2018 (2018). 
5. A. Caragliu, C. Del Bo, P. Nijkamp. Smart cities in Europe. Serie Research Memoranda 0048, (VU University Amsterdam, Faculty of Economics, Business Administration and Econometrics, 2009).

6. M. Peris-Ortiz, D.R. Bennett, Yábar, P.-B. Diana. Sustainable Smart Cities: Creating Spaces for Technological, Social and Business Development. (Springer, 2016).

7. R.G. Hollands. Will the real smart city please stand up? Intelligent, progressive or entrepreneurial? City, 12 (2008).

8. J.R. Gil-Garcia, T.A. Pardo, T. Name. What makes a city smart? Identifying core components and proposing an integrative and comprehensive conceptualization. Information Polity, 20 (2015).

9. H. Chourabi et al. Understanding Smart Cities: An Integrative Framework. 45th Hawaii International Conference on System Sciences, (Maui, HI, 2012).

10. P. Neirotti, A. De Marco, A.C. Cagliano, G. Mangano, F. Scorrano. Current trends in Smart City initiatives: Some stylized facts. Cities, 38 (2014).

11. URL: http://smartcities.gov.in/content/innerpage/what-is-smart-city.php.

12. J.R. Gil-Garcia, J. Zhang, G. Puron-Cid. Conceptualizing smartness in government: An integrative and multi-dimensional view. Government Information Quarterly, 33 (2016).

13. S.A. Bozhenov. Clever city in the development strategy of Belgorod. City management: theory and practice, 1 (2012). 